\title{
Karakterisasi Bionanofiller Dari Limbah Padi Sebagai Alternatif Penguatan Pada Polimer Komposit
}

\author{
Eryani $^{1}$, Sri Aprilia ${ }^{2 *}$, Farid Mulana ${ }^{2}$ \\ ${ }^{1}$ Program Magister Teknik Kimia, Fakultas Teknik, Universitas Syiah Kuala \\ ${ }^{2}$ Jurusan Teknik Kimia, Fakultas Teknik, Universitas Syiah Kuala \\ Jl. Tgk. Syech Abdurrauf 7, Fakultas Teknik, Universitas Syiah Kuala \\ Darussalam, Banda Aceh, 23111 \\ *Koresponden Email: sriaprilia@unsyiah.ac.id
}

Diterima: 25 Juli 2018

Disetujui: 1 Agustus 2018

\begin{abstract}
Agricultural waste such as rice straw, rice husk and rice husk ash have not been utilized properly. This waste of agricultural produce can actually be used as an alternative to bionanofiller because it contains an excellent source of silica. The silica content contained in the rice waste when combined with the polymer matrix can produce composites having high thermal and mechanical properties. Characterization of bionanofiller from this rice waste is done by SEM, XRF, FTIR, XRD and particle density. The result of SEM analysis from this rice waste is feasible to be used as filler because it has size $1 \mu \mathrm{m}$. Likewise with the results of XRF analysis that rice waste contains a high enough silica component that is $80.6255 \%-89.83 \%$. FTIR test results also show that bionanoparticles from rice waste have the same content of silica. In the XRD analysis the best selective gain of rice waste is found in rice husk ash which is characteristic of amorp silica at a range of $2 \Theta=22^{\circ}$. The largest density analysis of paddy waste was found in rice husk $0.0419 \mathrm{gr} / \mathrm{cm}^{3}$, followed by rice straw by of $0.0417 \mathrm{gr} / \mathrm{cm}^{3}$ and rice hulk ash $0.0407 \mathrm{~g} / \mathrm{cm}^{3}$
\end{abstract}

Keywords: bionanofiller, silica, polymer matrix, reinforcement, composite

Abstrak. Limbah hasil pertanian seperti jerami padi, sekam padi dan abu sekam padi selama ini belum dimanfaatkan secara baik. Limbah dari hasil pertanian ini sebenarnya dapat digunakan sebagai alternatif bionanofiller karena mengandung sumber silika yang sangat baik. Kandungan silika yang terdapat dalam limbah padi apabila dipadukan dengan matrik polimer dapat menghasilkan komposit yang memiliki sifat termal dan mekanik yang tinggi. Karakterisasi bionanofiller dari limbah padi ini dilakukan dengan SEM, XRF, FTIR, XRD dan density partikel. Hasil analisa SEM dari limbah padi ini layak digunakan sebagai filler karena sudah berukuran $1 \mu \mathrm{m}$. Begitu juga dengan hasil analisa XRF bahwa limbah padi mengandung komponen silika yang cukup tinggi yaitu kisaran $80.6255 \%-89,83 \%$. Hasil uji FTIR juga menunujukkan bahwa bionanopartikel dari limbah padi memiliki kandungan yang sama yaitu silika. Pada analisa XRD perolehan selika terbaik dari limbah padi terdapat pada abu sekam padi yang merupakan karakteristik silika amorp pada sudut kisaran $2 \Theta=22^{\circ}$. Hasil analisa densitas terbesar dari limbah padi terdapat pada sekam padi yaitu $0,0419 \mathrm{gr} / \mathrm{cm}^{3}$, diikuti oleh jerami padi sebesar $0,0417 \mathrm{gr} / \mathrm{cm}^{3}$ dan abu sekam padi sebesar $0,0407 \mathrm{gr} / \mathrm{cm}^{3}$.

Kata kunci: bionanofiller, silika, matrik polimer, penguat, komposit

\section{Pendahuluan}

Indonesia sebagai negara agraris dimana sebagian besar penduduknya menjadikan beras sebagai makanan pokok. Beras menghasilkan limbah jerami padi dan sekam padi yang berlimpah setelah dilakukan pemisahan beras 
Tabel 1. Komposisi sekam padi beserta zat organiknya

\begin{tabular}{|c|c|c|}
\hline No & Komponen & $\begin{array}{c}\text { Kandumgar } \\
(\omega / \infty)\end{array}$ \\
\hline I & Kudar air & 902 \\
\hline 2 & Protein kasar & 3,03 \\
\hline 3 & Lemak & 1,18 \\
\hline 4 & Scrat kasar & 35,68 \\
\hline 5 & Abu & 17,71 \\
\hline 6 & Katbohidrat kasar & 33,17 \\
\hline 7 & $\begin{array}{l}\text { Kalbon (zal } \\
\text { arang̣) }\end{array}$ & 1,33 \\
\hline 8 & Hidrogen & 1,51 \\
\hline 9 & Oksigen & 33,61 \\
\hline 10 & Silika $\left(\mathrm{SiO}_{2}\right)$ & 16,98 \\
\hline
\end{tabular}

Sumber : Nugraha dan Setyawati (2003)

dari tanaman padi (Umedah dan Kondoh, 2010). Selama ini sekam padi hanya digunakan sebagai bahan bakar untuk pembakaran batu merah dan sebagai sumber energi panas untuk keperluan manusia atau di buang begitu saja (Putro dan Sutiyoko, 2007) sedangkan jerami padi setelah dipisahkan dari biji padi hanya dibiarkan begitu saja. Karena keberadaan sekam padi terus meningkat, penanganan yang kurang tepat dapat menimbulkan pencemaran lingkungan dan juga kesehatan manusia. Hal ini disebabkan karena sekam padi mengalami proses penghancuran secara alami dan relatif lambat. Selain itu juga pembakaran 1 ton sekam padi akan menyebabkan

Tabel 2. Komposisi jerami padi

\begin{tabular}{clc} 
No & Komponen & Kamdumgan $(1 \%)$ \\
\hline 1 & Timituclulosa & 27,5 \\
2 & Selulosa & 39,1 \\
3 & Lignin & 12,5 \\
4 & abu & 11,5
\end{tabular}

Sumber : Karimi (2006)

$0,15 \mathrm{~kg} \mathrm{CO} 2$ sebagai gas emisi. Sekitar 0,09 kg gas metana $\left(\mathrm{CH}_{4}\right)$ dapat dihasilkan (Umedah dan Kondoh, 2010).Komposisi kimia sekam padi terlihat pada Tabel 1 .

Pemanfaatan kembali jerami padi dan sekam padi sebagai sumber energi dapat digunakan sebagai bahan biomasa. Hal ini karena jerami padi dan sekam padi mengandung $65-75 \%$ polisakarida organik sebagai selulosa dan hemiselulosa dan menjadi sumber bahan bakar yang sesuai untuk
Tabel 3. Komposisi abu sekam padi Sumber : Folleto (2006)

\begin{tabular}{ccc}
\hline No & Senyawa & l'ersentase \\
\hline 1 & $\mathrm{SiO}_{2}$ & 94,4 \\
2 & $\mathrm{Al} 2 \mathrm{O}_{3}$ & 0,61 \\
3 & $\mathrm{Fe} 2 \mathrm{O}_{3}$ & 0,03 \\
4 & $\mathrm{CaO}$ & 0,83 \\
5 & $\mathrm{M} 1 \mathrm{gO}$ & 1,21 \\
6 & $\mathrm{~K} 2 \mathrm{O}$ & 1.06 \\
7 & $\mathrm{Nin}_{2} \mathrm{O}$ & 0,77 \\
8 & $\mathrm{SO}$ & - \\
9 & $\mathrm{LOI}$ & - \\
Sumber : Folleto $(2006)$ &
\end{tabular}

energi generasi. Jerami padi dan sekam padi mengandung bahan silika sekitar 4-7\% dan 18$22 \%$ berat (Luh, 1991). Komposisi jerami padi terlihat pada Tabel 2.

Jenis limbah padilainyang terus dikembangkan pemanfaatannya adalah RHA (Rice Husk Ash). RHA merupakan abu yang dihasilkan dari pembakaran sekam padi. RHA merupakan salah satu bahan baku dalam mengasilkan silika. Saat ini pemakaian bahan baku berbasis silika merupakan teknologi yang terus dikembangkan, dimana dalam aplikasinya pemanfaatan nano silika telah digunakan dalam berbagai bidang, diantaranya di bidang industri dan sains. Pemanfaatan abu sekam padi untuk menghasilkan nano silika dengan cara sintesis telah banyak di lakukkan, diantaranya pengambilan tepung nanosilika dari abu sekam padi dengan menggunakan metode Precipitation (Thuadaij dan Nuntiya, 2008). Optimasi sintesis dan karakterissasi nanosilika dari abu sekam padi (Rafiee, dkk., 2012).

Abu sekam padi yang dihasilkan dari limbah sekam padi yang dibakar memiliki sifat pozolan aktif, dimana pada suhu kamar dapat bereaksi dengan kapur dengan menggunakan media air akan membentuk senyawa yang mengikat. Abu sekam padi juga mengandung senyawa silika yang sangat menonjol. Abu sekam padi jika di bakar pada suhu tinggi (antara 500-600 ${ }^{\circ} \mathrm{C}$ ) secara terkontrol akan menghasilkan abu silika yang dalam aplikasinya sering dimanfaatkan untuk berbagai macam proses kimia. Adapun komposisi kimia abu sekam padi dapat dilihat pada Tabel 3. 
Tabel 4. Hasil analisa densitas jerami padi, sekan padi dan abu sekam padi

\begin{tabular}{|c|c|c|c|}
\hline \multirow[b]{2}{*}{ Kusatular } & \multicolumn{3}{|c|}{ Simpel } \\
\hline & $\begin{array}{c}\text { Jcrami } \\
\text { pexti } \\
(2,1)\end{array}$ & $\begin{array}{c}\text { Sckam } \\
\text { pudi } \\
\text { (gr) }\end{array}$ & $\begin{array}{c}\text { Alus } \\
\text { sckam } \\
\text { [akdt } \\
\text { (Lr) }\end{array}$ \\
\hline $\begin{array}{c}\text { Massa sampel } \\
\text { axidl }\end{array}$ & 2 & 2 & 2 \\
\hline $\begin{array}{l}\text { Massa pikno } \\
\text { losong (mit) }\end{array}$ & 22.6060 & 22,660 & $22.6(0)$ \\
\hline $\begin{array}{c}\text { Xaksa sampel + } \\
\text { sif (111-) }\end{array}$ & 24.600 & 24,682 & $24.6 \mathrm{Z} 2$ \\
\hline $\begin{array}{l}\text { Massa pikm + } \\
\text { air (111-) }\end{array}$ & 47,422 & 47,422 & 47.422 \\
\hline $\begin{array}{c}\text { Wassa pikno } \\
\text { yalle berisi all } \\
\text { hescrta sanupel } \\
\text { (Jut) }\end{array}$ & $48_{x} 568$ & 48.148 & 47,854 \\
\hline $\begin{array}{l}\text { Densitas } \\
\text { (乡r:(⿻山') }\end{array}$ & 0,041 & 0.441 & 0,040 \\
\hline
\end{tabular}

Menurut Umedah dan Kondoh, 2008 limbah padi dapat digunakan sebagai alternatif bionano filler karena megandung sumber silika yang sangat baik. Silika merupakan senyawa anorganik yang dihasilkan setelah adanya perlakuan kimia dan diikuti oleh pembakaran (Carmona dkk, 2013). Menurut Prasad (2000), kandungan silika dalam sekam padi biasanya berkisar antara 94-96 $\%$ dan apabila nilainya mendekati atau di bawah 90\% kemungkinan disebabkan karena adanya kontaminasi dengan zat lain yang mangandung silika lebih rendah.

Silika memiliki sifat tahan aus, memiliki kekerasan, tahan terhadap panas dan memiliki kekuatan yang tinggi, sehingga dapat digunakan sebagai penguat. Kandungan silika yang terdapat dalam limbah padi apabila dipadukan dengan matriks dapat menghasilkan komposit yang memiliki sifat termal dan mekanik yang tinggi (Wong dkk, 2015).

Telah banyak dilakukkan pemanfaatan biomassa sebagai bionanofillerpada polimer matriks untuk mendapatkan material bionanokomposit yang memiliki sifat-sifat mekanika dan fisika yang baik dalam berbagai aplikasi. Penggunaan bionanofiller sebagai penguat sering digunakan pada polimer termoplastik, termoset dan elastomer. Dalam analisanya Aprilia, dkk (2014) mengatakan bahwa penambahan bionanofiller pada polimer matrik bertujuan untuk meningkatkan peforma yang baik pada material bionanokomposit di berbagai bidang aplikasi seperti: otomotiv, konstruksi,elektronik dan juga pengemasan, hal ini dikarenakan mereka memiliki densiti yang rendah, kekakuan yang baik, memiliki sifat-sifat termal dan mekanikal yang baik.

Bionanofiller merupakan bahan yang digunakan untuk meningkatkan sifat-sifat suatu komposit dengan cara menambahkannya kedalam matrik polimer. Jawaid dan Abdul Khalil (2011) mengatakan bahwa bahan pengisi (filler) yang telah banyak diteliti dan digunakan sebagai penguat dalam polimer komposit adalah batang, daun, buah, biji, kulit kayu dan jenis rumput-rumputan, namun dalam aplikasinya penggunaan daun dan batang lebih komersial dibandingkan dengan yang lainnya.

Pemanfaatan bionanofiller sebagai penguat pada polimer komposit memiliki beberapa keuntungan, seperti biaya yang rendah, densitas rendah, sumber daya alam yang dapat diperbaharui, mudah dalam preparasi, biodegradabel, hanya membutuhkan energi yang rendah untuk proses, penggunaan yang luas dan relatif non abrasif dibandingkan dengan penguat yang menggunakan bahan tradisional (Kim dkk, 2007; Mekonnen dkk, 2013).

Dalam tulisannya La Mantia (2005) mengatakan bahwa pada awalnya filler yang digunakan sebagai penguat pada polimer matrik adalah yang berasal dari bahan anorganik. akan tetapi karena bahan anorganik merupakan sumberdaya yang tidak dapat diperbaharui, dan alasan lingkungan maka penggunaan filler dari limbah pertanian perlu untuk dipertimbangkan dan dikembangkan. Penggunaan filler dari bahan organik lebih disukai karena ketersediaannya cukup berlimpah, mudah diperoleh, dapat diperbaharui dan meningkatkan harga bahan baku dan energi.

Sifat suatu bahan pengisi (filler) akan cocok dengan matriks polimer, jika dipengaruhi oleh beberapa faktor antara lain : ukuran partikel suatu bahan pengisi (filler), dimana ukuran partikel suatu bahan pengisi (filler) yang berukuran nano dapat meningkatkan derajat penguatan polimer dibandingkan dengan ukuran yang lebih besar (Leblance dan Rrubber, 2002). Begitu juga dengan 


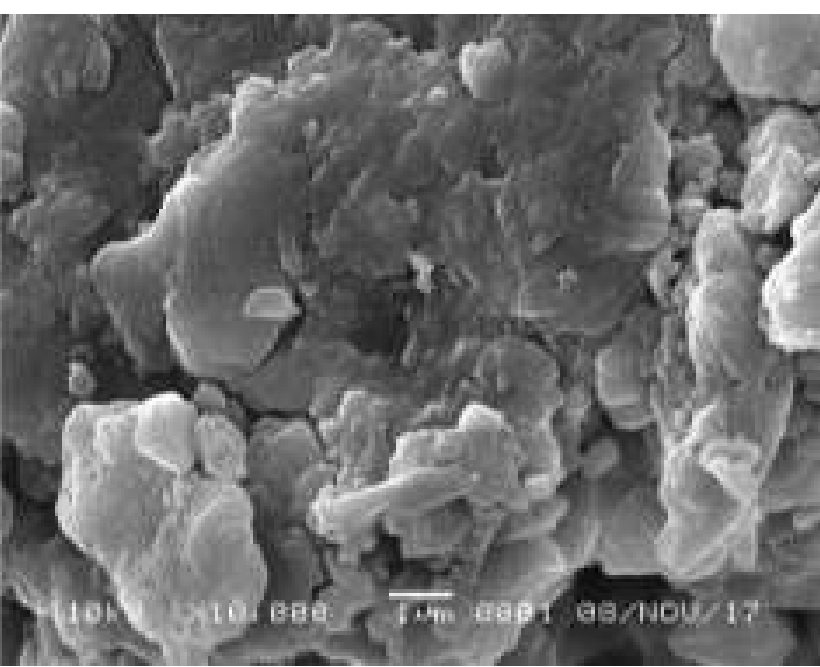

Gambar 1. Analisis SEM bionanopartikel jerami padi

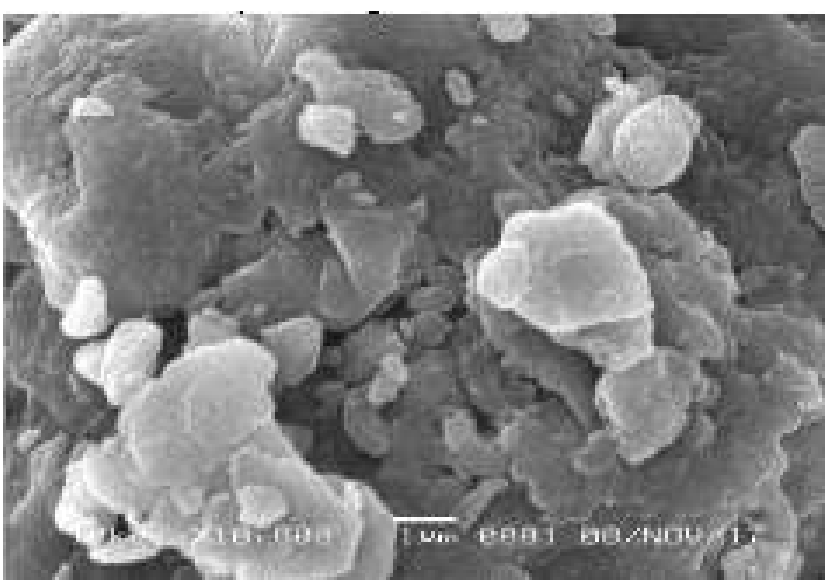

Gambar 2. Analisis SEM bionanopartikel sekam padi

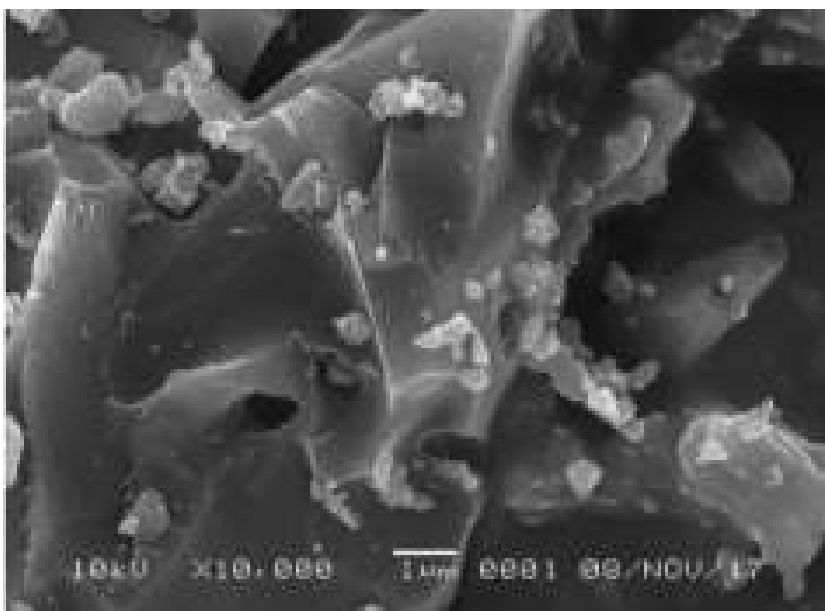

Gambar 3. Analisis SEM bionanopartikel abu sekam padi

semakin nano ukuran partikel semakin tinggi ikatan antara bahan pengisi (filler) dengan matriks polimer (Kohls dan Beaucage, 2002). Jumlah luas permukaan dapat lebih meningkat dengan adanya permukaan yang berpori pada permukaan bahan pengisi. Begitu juga halnya dengan penambahan
Tabel 5. Hasil analisa XRF jerami padi, sekan padi dan abu sekam padi

\begin{tabular}{|c|c|c|c|c|}
\hline \multirow[b]{2}{*}{$\underset{\text { Kon }}{\text { Koicpo }}$} & \multicolumn{3}{|c|}{ Kutiar } & \multirow[b]{2}{*}{ Lnit } \\
\hline & $\begin{array}{c}\text { Jerani } \\
\text { Padi }\end{array}$ & $\begin{array}{c}\text { Sckanı } \\
\text { Tadi }\end{array}$ & $\begin{array}{c}\text { Ablu } \\
\text { Sekiud } \\
\text { Padi }\end{array}$ & \\
\hline $\mathrm{SiO}:$ & 80.625 & 82.54 & 89.83 & $\%$ \\
\hline $\mathrm{l}_{2} \mathrm{e}_{2} \mathrm{U}_{3}$ & 1.968 & 11.02 & 1.33 & $\%$ \\
\hline $\mathrm{CaO}$ & 6.72 & 1.500 & $1.4 \%$ & $\%$ \\
\hline $\operatorname{MnO}$ & $80 . \leqslant 25$ & 1.49 & 0.512 & $y_{11}$ \\
\hline $\mathrm{K}, \mathrm{O}$ & 1533 & 1115 & 3,49 & 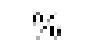 \\
\hline $\mathrm{MgO}$ & 0.422 & 1.1155 & 1.734 & $\%$ \\
\hline P2Os & 2715 & $\|s\|$ & 11.661 & 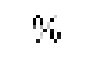 \\
\hline $\mathrm{SO}_{3}$ & 0.422 & 0.214 & 0.213 & $\%$ \\
\hline $\mathrm{N}_{2} \mathrm{O}$ & 0.187 & 0.254 & 0.268 & $\psi_{0}$ \\
\hline $\mathrm{Al}_{2} \mathrm{O}_{3}$ & 0.232 & 0.174 & 0.446 & 然 \\
\hline $\mathrm{SiO}$ & 0.024 & 0.028 & 0.612 & 紧 \\
\hline
\end{tabular}

bionanofiller dapat meningkatkan sifat mekanik dan termal pada material komposit (Bukit, 2012).

Material komposit didefinisikan sebagai kombinasi antara dua material atau lebih yang secara makroskopis berbeda bentuk dan komposisi kimianya, serta tidak saling melarutkan antara materialnya, dimana material yang satu berfungsi sebagai penguat (Reinforcement) dan material yang lainnya berfungsi sebagai pengikat (matrik) sehingga akan terbentuk material baru yang lebih baik dari material penyusunnya (Sisworo, 2009).

Bhagwan dan Agarwal (1980), mengatakan bahwa sifat, distribusi unsur penyusun dan interaksi keduanya sangat mempengaruhi sifat dari bahan komposit. Selain itu, bentuk, ukuran, distribusi dari filler dan ciri-ciri dari matrik merupakan parameter lain yang mungkin mempengaruhi sifat dari bahan komposit (Mathew dan Rawlings, 1994). Sifat mekanik juga merupakan salah satu sifat yang penting dalam bahan komposit, dimana untuk aplikasi struktur sifat mekanik sangat di tentukan oleh pemilihan bahan (Colling, dkk., 1995). Dengan kata lain sifat mekanik bahan komposit bergantung pada sifat bahan penyusunnya.

Karakteristik material komposit menunjukkan kestabilan thermal dan peningkatan sifat mekanik dari komposit hanya dengan menambahkan 


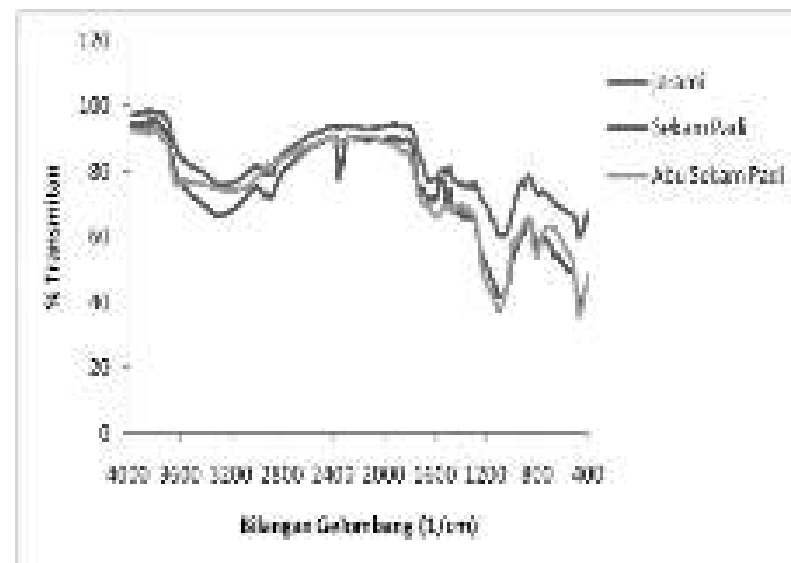

Gambar 4. Hasil Analisa FTIR Bionanopartikel Jerami Padi, Sekam Padi dan Abu Sekam Padi

sedikit bahan pengisi berukuran nano $(<10 \%)$. Selain itu juga memberikan keuntungan karena memiliki sifat biokompatibel dan biodegradabel serta memiliki sifat khusus sesuai dengan sifat bahan pengisi yang dipergunakan. (Carmago, 2009 dan Zhao, 2008).

Sifat dan karakteristik bionanokomposit juga dipengaruhi oleh matrik yang digunakan, dimana matrik merupakan bahan yang berfungsi sebagai pengikat dan pengukuh serta memberikan bentuk dalam komposit (Xanthos, 2005). Fungsi penting matrik dalam komposit (Mazumdar, 2002) adalah:

1. Mengikat filler dan mentransfer beban ke filler untuk menghasilkan kekuatan dan membentuk struktur komposit.

2. Memberikan kualitas yang baik pada permukaan komposit.

3. Dapat memperlambat atau menghentikan penyebaran retakan.

4. Untuk memperkuat filler terhadap serangan kimia dan kerusakan mekanik karena pemakaian.

Bahan matrik umumnya dapat berupa logam, polimer, keramik, dan karbon. Pembuatan komposit membutuhkan ikatan permukaan yang kuat antara pengisi dan matrik, dimana matrik dalam komposit itu berperan sebagai bahan pengikat (Darder, 2007).

\section{Metodelogi Penelitian}

\subsection{Bahan dan Alat}

Bahan baku yang digunakan dalam penelitian ini adalah limbah dari hasil pertanianyaitu jerami

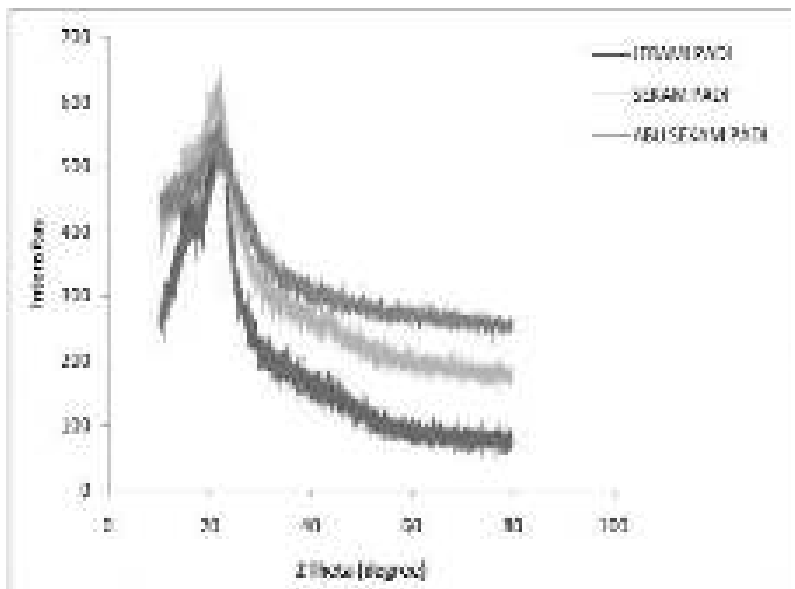

Gambar 5. Analisis XRD bionanopartikel jerami padi, sekam padi dan abu sekam padi

padi, sekam padi dan abu sekam padi yang diperoleh dari limbah padi dipersawahan Aceh Besar. Peralatan yang digunakan adalah Ball mill(Fritsch Pulverisette)dan ayakan ukuran 325 mesh (Macross Testing Sieve).

\subsection{Pembuatan Filler}

Bionanofiller dipersiapkan dari bahan baku jerami padi, sekam padi, dan abu sekam padi. Bahan-bahan ini dicuci bersih dan dikeringkan dengan sinar matahari. Kemudian jerami padi dipotong-potong dengan ukuran $\pm 1 \mathrm{~cm}$. Lalu bahan baku tersebut dikeringkan dalam oven selama 24 jam pada temperatur $80^{\circ} \mathrm{C}$. Jerami padi, sekam padi dan abu sekam padi lalu dihaluskan dengan menggunakan blender. Untuk memperoleh ukuran nano bahan ini digiling halus didalam ball mill sampai mencapai ukuran nano. Kemudian diayak dengan menggunakan sieving ukuran 325 mesh. Nanofiller yang dihasilkan dilakukan karakterisasi. Karakterisasi dilakukan dengan analisis densitas partikel, SEM, XRF, FTIR, dan XRD.

\subsection{Karakterisasi Filler}

\section{Densitas}

Densitas atau yang biasa disebut sebagai massa jenis merupakan ukuran kerapatan dari suatu material. Analisis densitas jerami padi, sekam padi dan abu sekam padi dimulai dengan menimbang masing-masing sampel (berupa serbuk) sekitar 2 gram, lalu menimbang massa piknometer 
kosong sebagai $\left(\mathrm{m}_{1}\right)$, menimbang massa air yang dimasukkan kedalam piknometer sebagai $\left(\mathrm{m}_{2}\right)$, menimbang massa piknometer yang berisi serbuk sebagai $\left(\mathrm{m}_{3}\right)$, dan menimbang massa serbuk dan air yang terisi didalam piknometer sebagai $\left(\mathrm{m}_{4}\right)$. Setelah mendapatkan $\mathrm{m}_{1}, \mathrm{~m}_{2}, \mathrm{~m}_{3}$ dan $\mathrm{m}_{4}$ maka dilakukkan perhitungan untuk mengetahui nilai densitasnya dengan menggunakan persamaan:

Dimana:

$$
\rho=\frac{(m 2-m 1)}{(m 3-m 1)+(m 4-m 2)} \times \rho_{\text {air. }}
$$

$$
\begin{aligned}
\rho= & \text { masssa jenis }(\mathrm{gr} / \mathrm{cm} 3) \\
\mathrm{m} 1= & \text { massa pikno kosong }+ \text { tutup }(\mathrm{gr}) \\
\mathrm{m} 2= & \text { massa pikno kosong }+ \text { tutup }+ \text { bahan } \\
& (\mathrm{gr}) \\
\mathrm{m} 3= & \text { massa pikono }+ \text { tutup }+ \text { fluida }(\mathrm{gr}) \\
\mathrm{m} 4= & \text { massa pikno }+ \text { tutup }+ \text { bahan }+ \text { fluida }
\end{aligned}
$$$$
\text { (gr) }
$$

\section{SEM}

Pengujian SEM dilakukan untuk mengetahui struktur morfologi pada suatu material dalam ukuran mikron. Pada analisa SEM ini jenis alat instrumen yang digunakan adalah JEOL JSM 35-C dengan perbesaran 10.000 kali. Analisis SEM dimulai dengan memasukkan sampel yang akan dianalisis ke vacum column, dimana udara akan dipompa keluar untuk menciptakan kondisi vakum. Kondisi vakum ini diperlukan agar tidak ada molekul gas yang dapat mengganggu jalannya elektron selama proses berlangsung. lalu elektron ditembakkan dan akan melewati berbagai lensa yang ada menuju ke satu titik di sampel. Selanjutnya sinar elektron akan dipantulkan ke detektor lalu ke amplifier untuk memperkuat sinyal sebelum masuk ke komputer untuk menampilkan gambar yang diinginkan.

\section{XRF}

Pengujian menggunakan XRF dilakukan berdasarkan identifikasi dan pencacahan karakteristik sinar-X yang terjadi dari peristiwa efekfotolistrik. Analisis XRF dilakukkan untuk mengetahui komposisi kimia yang terdapat pada jerami padi, sekam padi dan abu sekam padi. Langkah-langkah pada analisis XRF yaitu disiapkan sampel yang akan diuji. Kemudian sampel diletakkan didalam sampel holder, dipastikan bagian bawah sampel holder tertutupi seluruhnya oleh sampel karena bagian inilah yang akan ditembaki oleh sinar-X. Setelah sampel siap pada sampel holder, tutup Lid dan dijalankan XRF menggunakan tombol ON.

Analisis akan langsung berjalan dengan menggunakan tombol untuk penyinaran sinar-X. Sampel akan dikenai sinar-X untuk beberapa saat. Sinar-X yang mengenai sampel akan diteruskan ke detektor dan selanjutnya dianalisis unsurunsur yang terkandung dalam sampel, kemudian dilakukkan pemotretan hasil.

\section{FTIR}

Pengujian Analisa FTIR digunakan untuk mengidentifikasi kandungan gugus fungsi pada senyawa dengan melihat ikatan yang dihasilkan ketika radiasi infrared ditembakkan pada sampel. Analisis gugus fungsi dengan sampel limbah padi (jerami padi, sekam padi dan abu sekam padi) ini dilakukan dengan menggunakan alat Shimadzu Prestige FT-IR 6400 dengan panjang gelombang $4000-400 \mathrm{~cm}^{-1}$. Langkah-langkah yang dilakukan pada analisis FTIR yaitu sampel yang sudah halus ditimbang, dan menimbang sampel padat (bebas air). Selanjutnya mencampur KBr dan sampel ke dalam mortar dan diaduk hingga keduanya rata.

Disiapkan cetakan pellet, mencuci bagian sampel, base dan tablet frame dengan kloroform. Selanjutnya memasukkan sampel $\mathrm{KBr}$ yang telah dicampur dengan set cetakan pellet, lalu dihubungkan dengan pompa vakum untuk meminimalkan kadar air. Meletakkan cetakan pompa hidrolik dan memberikan tekanan sebesar 8 gauge. Dihidupkan pompa vakum selama 15 menit, kemudian mematikan pompa vakum, dan menurunkan tekanan dalam cetakan dengan cara membuka keran udara. Selanjutnya melepaskan pellet $\mathrm{KBr}$ yang telah terbentuk dan menempatkan pellet $\mathrm{KBr}$ pada tablet holder.

Menghidupkan alat dengan mengalirkan sumber arus listrik, alat interferometer dan computer. Mengklik "shortcut FTIR 8400” pada layar komputer yang menandakan program 
interferometer. Lalu menempatkan sampel dalam alat interferometer, dan mengklik FTIR 8400 pada komputer serta mengisi data. Mengklik "sampel start" untuk memulai, dan untuk memunculkan harga bilangan gelombang mengklik "clac" pada menu, kemudian mengklik "peak table" dan mengklik "OK". Terakhir mematikan komputer, alat interferometer dan sumber listrik.

\section{XRD}

Pengujian XRD ini dilakukkan untuk menganalisis suatu bahan padatan kristalin yang terdapat pada jerami padi, sekam padi dan abu sekam padi. Analisis struktur kristal filler dilakukkan dengan alat Shimadzu Maxima XRD-7000. Analisis XRD dilakukan dengan menyiapkan sampel yang akan dianalisis, yaitu sampel yang sudah disintering pada suhu $800^{\circ} \mathrm{C}$, $900^{\circ} \mathrm{C}$ dan $1000^{\circ} \mathrm{C}$. Kemudian direkatkan pada kaca dan dipasang pada tempatnya berupa lempeng tipis berbentuk persegi panjang (sampel holder) dengan lilin perekat. Memasang sampel yang telah disimpan pada sampel holder kemudian diletakkan pada sampel stand di bagian goniometer.

Memasukkan parameter pengukuran pada software pengukuran melalui computer pengontrol, yaitu meliputi penentuan scan mode, penentuan rentang sudut, kecepatan scan cuplikan, memberi nama cuplikan dan memberi nomor urut file data. Selanjutnya alat difraktometer dioperasikan dengan perintah "start" pada menu computer, dimana sinar-x akan meradiasi sampel yang terpancar dari target $\mathrm{Cu}$ dengan panjang gelombang 1,5406 A.

Melihat hasil difraksi pada komputer dan intensitas difraksi pada sudut $2 \Theta$ tertentu dapat dicetak oleh mesin printer. Kemudian mengambil sampel setelah pengukuran cuplikan selesai. Data yang terekam berupa sudut difraksi $(2 \Theta)$, besarnya intensitas (I), dan waktu pencatatan per langkah $(\mathrm{t})$. Setelah data diperoleh analisis kualitatif dengan menggunakan search match analisys yaitu membandingkan data yang diperoleh dengan data standar (data base PDF = Powder Diffraktion File data Base).

\section{Hasil dan Pembahasan \\ 4.1 Densitas}

Hasil analisis densitas menunjukkan bahwa pada tiga jenis limbah padi (jerami padi, sekam padi dan abu sekam padi) nilai densitas paling kecil terdapat pada abu sekam padi sebesar $0,040 \mathrm{gr} / \mathrm{cm}^{3}$, kemudian diikuti oleh jerami padi dan sekam padi sebesar $0,041 \mathrm{gr} / \mathrm{cm}^{3}$. Kecilnya nilai densitas yang diperoleh abu sekam padi menjelaskan bahwa semakin besar ronggarongga antar filler (partikel). Nilai densitas abu sekam padi juga menunjukkan bahwa filler abu sekam padi adalah yang paling halus dari kedua jenis filler lainnya, hal ini juga dapat dilihat dari hasil analisis SEM yang diperoleh (Gambar 3). Data hasil uji densitas dapat dilihat pada Tabel 4.

\subsection{Stuktur Filler}

Hasil analisis SEM jerami padi, sekam padi dan abu sekam padi dapat dilihat pada Gambar 1,2 dan 3.

Gambar 1, Gambar 2 dan Gambar 3 menunjukkan struktur morfologi permukaan pada jerami padi, sekam padi dan abu sekam padi. Hasil SEM terlihat bahwa sampel sudah berukuran nano dalam skala lebih kurang $0,001 \mu \mathrm{m}$, dengan demikian partikel dari jermi padi, sekam padi dan abu sekam padi layak digunakan sebagai pengisi pada polimer komposit.

\subsection{Komposisi Kimia Filler}

Hasil analisis XRF menunjukkan fraksi komponen silika yang paling tinggi terdapat pada abu sekam padi yaitu sebesar $89,83 \%$, sedangkan pada sekam padi sebesar $82,54 \%$, dan jerami padi sebesar $80,625 \%$.

Dari hasil penelitiaan Chandrasekar (2006) mengatakan bahwa, kenaikan fraksi komponen silika pada abu sekam padi disebabkan karena adanya proses pembakaran dari sekam padi menjadi abu sekam padi. Silika yang terkandung didalam sekam padi memiliki sifat sangat reaktif dan amorf, sehingga dengan adanya proses pembakaran tersebut dapat meningkatkan kualitas kandungan silika. Selain silika, pada abu sekam 
padi juga terdapat kandungan $\mathrm{Fe} 2 \mathrm{O}_{3}$ (besi), $\mathrm{CaO}$ (Kalsium Oksida), dan $\mathrm{MnO}$ (Mangan Oksida) yang lebih kecil dibandingkan dengan jerami padi dan sekam padi. Hal ini menunujukkan bahwa proses pembakaran mempengaruhi berkurangnya kandungan pengotor di dalam sekam dan sebaliknya meningkatkan kemurnian silika.Data hasil analisis XRD dapat dilihat pada Tabel 5.

\subsection{Gugus Fungsi Filler}

Hasil analisis spektrum FTIR yang diperoleh dapat dilihat pada Gambar 4:

Gambar 4. merupakan hasil analisis FTIR bionanopartikel jerami padi, sekam padi dan abu sekam padi. Dari Gambar 4 terlihat secara keseluruhan spektra bionanopartikel dari limbah padi (jerami padi, sekam padi dan abu sekam padi) memiliki struktur spektra yang hampir sama yaitu menunujukan gugus fungsi silika ( $\mathrm{Si}-\mathrm{O}-\mathrm{Si}$ ) pada panjang gelombang $1095-1075 \mathrm{~cm}^{-1}$.

Hal tersebut dapat menjelaskan bahwa bionanopartikel dari limbah padi tersebut memiliki kandungan yang sama yaitu silika. Selain itu juga terdapat ikatan $(\mathrm{C}-\mathrm{H})$ yang merupakan gugus fungsi aromatik pada panjang gelombang 2935$2915 \mathrm{~cm}^{-1}$. Selain memiliki struktur spektra yang sama, juga terdapat beberapa perbedaan spektra yaitu pada sekam padi dengan panjang gelombang $2934 \mathrm{~cm}^{-1}$ terdapat ikatan $(\mathrm{C}-\mathrm{H})$ yang merupakan gugus fungsi alkana.

\subsection{Derajat Kristalinitas Filler}

Hasil analisis XRD dapat dilihat pada Gambar 5:

Berdasarkan hasil uji XRD (Gambar 5) silika yang diperoleh dari jerami padi dan sekam padi lebih sedikit dibandingkan dengan silika yang terdapat didalam abu sekam padi, hal ini dapat dilihat dari puncak yang lebih landai pada dari abu sekam padi pada kisaran $2 \Theta=22^{\circ}$ yang merupakan karakteristik silika amorph. Puncak yang landai ini menunujukkan bahwa pada abu sekam padi memiliki struktur padatan amorf (Krishnarao, 1992). Dari penelitiannya (Sapei,dkk, 2012 ; Umeda dan Kondoh 2008) juga mengatakan bahwa silika yang diisolasi dari sekam padi memiliki struktur amorf, dan silika yang terdapat didalam tanaman pada umumnya bersifat amorph (Sapei, 2007).

\section{Kesimpulan}

Berdasarkan hasil penelitian dan pembahasan, maka dapat ditarik ditarik kesimpulan :

1. Limbah padi (jerami padi, sekam padi dan abu sekam padi) yang telah dihaluskan didalam ballmill selama 20 jam layak digunakan sebagai filler karena sudah berukuran $1 \mu \mathrm{m}$.

2. Data hasil uji XRF menunjukkan fraksi komponen silika tertinggi terdapat pada abu sekam padi, diikuti oleh sekam padi dan jerami padi.

3. Dari analisa gugus fungsi filler limbah padi, diketahui bahwa limbah padi tersebut memiliki struktur spektra yang hampir sama yaitu menunjukkan adanya gugus fungsi silika dan gugus fungsi aromatik.

4. Hasil uji XRD juga menunjukkan perolehan silika pada abu sekam padi lebih banyak dibandingkan dengan jerami padi dan abu sekam padi.

5. Dari hasil perhitungan densitas dapat diketahui bahwa nilai densitas jerami padi menunjukkan bahwa filler jerami padi adalah yang paling halus dari kedua jenis filler lainnya

\section{Daftar Pustaka}

Aprilia, S, N, A, Abdul Khalil, H, P, S, Bhat, A, H, Dungani, R \& Hossain, Md, S, (2014), 'Exploring Material properties of vinyl ester biocomposites filled carbonized jatropha seed shell', Bioresources, 9 (3), pp.4888-4898.

Bhagwan, D., Agarwal, (1980), Analysis and 38 Performance of Fiber Composite, John Wiley $\&$ Sons, New York

Bukit, N, (2012), 'Mechanical and Thermal Properties Of Polypropylene Reinforced by Calcined And Uncalcined Zeolite Makara Technology', 16(2), pp.121-128

Carmago, P, H, (2009), 'Nanocomposites : Synthesis, structure, properties and new application opportunities', Materials Research , 12(1), pp.1-39. 
Carmona, V, B,Oliveira, R, M,Silva,W, T, L,Mattoso,L, H, C\&Marconcini, J, M, (2013), 'Nanosilica from rice husk: Extraction and characterization', Industrial Crops and Products, 43, pp.291- 296

Colling, Davida \& Vasilos, T, (1995), Industrial Material: Polyme Ceramics and Composite, 2, Prentice Hall.

Darder, M, A, H, (2007), 'Bionanocomposite : A new concep to fecological, bioinspired, and fuctinal hybrid materials', Advance Materials, 19, pp.1309-1319

Folleto, E, L, Ederson, G, Leonardo, H, O \&Sergio, J, (2006), 'Conversion of Rice Hull Ash Into Sodium Silicate', Material Research, 9(3), pp.335- 338 .

Jawaid,M,AbdulKhalil,H, P, S, (2011), ' Cellulosic/ synthetic fibrereinforced polymer hybrid posites', Areview,CarbohydratePolymers, 86, pp.1-18.

Karimi, K, (2006), 'Conversion Of Rice Straw To Sugars By Dilute-Acid Hydrolysis',Biomass and Bioenergy, 30, pp 247-253

Kim,H, S, Choi, S, W, Lee, B, H, Kim,S, Kim, H. J, Cho C. W. \& Cho, D, (2007), 'Thermal properties of bio flour filled polypropilene bio-composites with different pozzolan contents', Journal of Thermal Analysis and Calorimetry, 89(3), pp. 821-82

Kohls,J, L, \& Beaucage, (2002),Rational Desing of Reinforced Rubber, Cur OP. Solid St Mat Sci ,6, pp 183-194

Krishnarao, R, V, Subrahmanyam, J, \& Kumar, T,J, (2001) 'Studies on The Formation of Black Particles in Rice Husk Silica Ash', Journal of the European Ceramic Society,21, pp. 99-104.

La Mantia, F.P, Morreale, M, \& Mohd Ishak, Z.A, (2005), 'Processing and Mechanical Properties of Organic Filler-Polypropylene Composites', Journal of Applied Polymer Science, 96, pp 1906-1913

Leblance, J, Rrubber (2002),filler Interaction and 2 Rheology properties in Filled Coumpaund, Prog .Polym . Sci 27, pp. 627-687

Luh, B, S, (1991), Rice Utilization, Second
Edition, Vol. 2, Van Nostrand Reinhold, USA. Mathew, F. L, Andr, D, \& Rawlings, (1994), Composite Materials: Engineering and Science, Chapman \& Hall, London.

Mazumdar, S. K, (2002), Composites Manufacturing Materials Product and Process Engineering, CRC Press LLC, 2000 N.W. Corporate Blvd., Boca Raton, Florida, 3(3), pp.431.

Mekonnen, T, Mussone, P, Alemaskin, K, Sopkow, L, Wolodko, J, Choi, P \& Bressler, D (2013), 'Biocomposites from hydrolyzed waste proteinaceous biomass: mechanical, thermal and moisture absorption performances', J. Mater. Chem. A, 1, pp.13186-13196.

Nugraha, S, Setiawati, J, (2003), 'Peluang Agribisnis Arang Sekam', Warta Litbang Pertanian Indonesia, Balai Penelitian Pascapanen Pertanian, 25(4), pp.1-2.

Prasad, C, S,(2000), ' Effect of rice husk ash in whiteware compositions', Ceramic International, 27(1), pp. 629-635

PutroA, L,\& Prasetyoko, D, (2007), 'Abu Sekam Padi Sebagai Sumber Silika Pada Sintesis Zeolit ZSM-5 Tanpa Menggunakan Templat Organik', Akta Kimindo3 (1), pp.33 -36.

Rafiee, E, Shahebrahimi, S, Feyzi, M \& Shaterzadeh, M (2012), 'Optimization of synthesis and characterization of nanosilica produced from rice husk (a common waste material)' International Nano Letters, 2, pp.29.

Sapei, L, Gierlinger, N, Hartmann, J, Nöske, R,S trauch \& P, Paris, O,(2007), 'Structural and Analytical Studies of Silica Accumulations in Equisetum hyemale', Journal of Analytical and Bioanalytical Chemistry,389, pp.1249-1257.

Sapei, L, Miryanti, A \& Widjaja, L.B, (2012), 'Isolas dan Karakterisasi Silika dari Sekam Padi dengan Perlakuan Awal Menggunakan Asam Klorida', Prosiding SINTECH-1 The First Symposium in Industrial Technology, Fakultas Teknologi Industri UPN Veteran Yogyakarta, A-8 - A-16. ISSN: 2302-8033.

Sisworo, S (2009), 'Pengaruh penggunaan serat kulit rotan sebagai penguat pada komposit polimer dengan matriks polyester yucalac 157 
terhadap kekuatan tarik dan tekuk',Jurnal Teknik,30( 3), pp.10.

Thuadaij, N \& Nuntiya, A, (2008), 'Preparation of Nanosilica Powder from Rice Husk Ash by Precipitation Method', Chiang Mai J. Sci, 3(1), pp. 206-2011

Umeda,J, \&Kondoh,K (2010), 'High-purification of amorphous silica originated from rice husks by combination of polysacchari dehydrolysis and metallic impurities removal', Industrial Crops and Products, 32, pp.539-544.

Umeda, J \& Kondoh, K (2008), 'High-Purity Amorphous Silica Originated in Rice Husks via Carboxylic Acid Leaching
Process', Journal of Materials Science, 43(22), pp.7084-7090.

Wong, J. C. H. H, Kaymak, P, Tingaut, S, Brunner, M. M \& Koebel, (2015),' Mechanical and thermal properties of nanofibrillated cellulose reinforced silica aerogel composites', Microporous and Mesoporous Materials, 217, pp.150-158.

Xanthos, M (2005), Functional Fillers for Plastics. WILEY-VCH Verlag Gmbh \& Co KgaA.

Zhao, R, E, (2008), 'Emerging Biodegradabel Material : starch and protein based bionanocomposites', Journal Materials Science, 43 (DOI 10.1007/s10853-007-2434-8), 30 (58), pp. 3071. 